\title{
Gender and the First World War
}

Edited by

Christa Hämmerle

Oswald Überegger

and

Birgitta Bader Zaar

14

16

17

18

19

20

21

22

(†) 23

25

26

27

28

29

30

31

32

33

34

35

36

37

38

39

40

41

42

43 macmillan 
Editorial matter, selection and introduction

(c) Christa Hämmerle, Oswald Überegger and Birgitta Bader Zaar, 2014

Remaining chapters (c) Respective authors 2014

All rights reserved. No reproduction, copy or transmission of this publication may be made without written permission.

No portion of this publication may be reproduced, copied or transmitted save with written permission or in accordance with the provisions of the Copyright, Designs and Patents Act 1988, or under the terms of any licence permitting limited copying issued by the Copyright Licensing Agency, Saffron House, 6-10 Kirby Street, London EC1N 8TS.

Any person who does any unauthorized act in relation to this publication may be liable to criminal prosecution and civil claims for damages.

The authors have asserted their rights to be identified as the authors of this work in accordance with the Copyright, Designs and Patents Act 1988.

First published 2014 by

PALGRAVE MACMILLAN

Palgrave Macmillan in the UK is an imprint of Macmillan Publishers Limited, registered in England, company number 785998, of Houndmills, Basingstoke, Hampshire RG21 6XS.

Palgrave Macmillan in the US is a division of St Martin's Press LLC, 175 Fifth Avenue, New York, NY 10010.

Palgrave Macmillan is the global academic imprint of the above companies and has companies and representatives throughout the world.

Palgrave ${ }^{\circledR}$ and Macmillan ${ }^{\circledR}$ are registered trademarks in the United States, the United Kingdom, Europe and other countries.

ISBN 978-1-137-30219-9

This book is printed on paper suitable for recycling and made from fully managed and sustained forest sources. Logging, pulping and manufacturing processes are expected to conform to the environmental regulations of the country of origin. A catalogue record for this book is available from the British Library. A catalog record for this book is available from the Library of Congress.

Typeset by MPS Limited, Chennai, India. 


\section{Proof}

\section{Contents}

List of Illustrations and Maps vii

Acknowledgements viii

Notes on Contributors $\quad$ ix

1 Introduction: Women's and Gender History

Christa Hämmerle, Oswald Überegger and Birgitta Bader Zaar

2 Women Behind the Lines: The Friuli Region

as a Case Study of Total Mobilization, 1915-1917 16

Matteo Ermacora

3 Imagining and Communicating Violence: The Correspondence of a Berlin Family, 1914-1918

Dorothee Wierling

4 Love in the Trenches: German Soldiers' Conceptions of Sexual Deviance and Hegemonic Masculinity in the First World War Jason Crouthamel

5 Visualizing 'War Hysterics': Strategies of Feminization and Re-Masculinization in Scientific Cinematography, 1916-1918 Julia Barbara Köhne

6 'Mentally broken, physically a wreck ...': Violence in War Accounts of Nurses in Austro-Hungarian Service Christa Hämmerle

7 Remembering French and British First World War Heroines Alison S. Fell

8 The Baby in the Gas Mask: Motherhood, Wartime Technology, and the Gendered Division between the Fronts during and after the First World War Susan R. Grayzel

9 The Female Mourner: Gender and the Moral Economy of Grief during the First World War Claudia Siebrecht

10 French Boys and Girls in the Great War: Gender and the History of Children's Experiences, 1914-1918 Manon Pignot 
vi Contents

11 Towards a New Internationalism: Pacifist Journals Edited by Women, 1914-1919 Bruna Bianchi

12 'A foolish dream of sisterhood': Anti-Pacifist Debates in the German Women's Movement, 1914-1919 Ingrid Sharp

13 War Activities and Citizenship Rights in and outside the Occupied Zone: Lithuanian Women during the First World War Virginija Jureniene

14 Love for the Nation in Times of War: Strategies and Discourses of the National and Political Mobilization of Slovene Women in Carinthia from 1917 to 1920 Tina Bahovec

\section{Select Bibliography}

Index 


\title{
2 \\ Women Behind the Lines: The Friuli Region as a Case Study of Total Mobilization, 1915-1917
}

\author{
Matteo Ermacora
}

During the First World War, the northeastern border region known as Friuli became a rear area of the Italian front. ${ }^{1}$ In this period people experienced 'total war' not only due to an extensive use of civilian workers in the context of the logistic efforts of the Italian Army, but also through the militarization of society, through air strikes, internments, and new forms of military control. After the defeat of Caporetto in October $1917,{ }^{2}$ part of the population managed to flee towards other Italian regions, while the others had to bear the harsh Austro-German occupation until the end of the war. ${ }^{3}$

Within this framework, women were deeply involved in the war. In this chapter I examine wartime mobilization of women from the lower class, their changing role, and the relationship between women and wartime society. In addition, I consider the question of how the state and religious authorities tried to maintain traditional gender roles behind the front. Finally, I will compare wartime representations of women and women's subjective perspectives. For this purpose, I refer to various sources such as military and civil administration records, letters and diaries, parish books, newspapers, and interviews conducted between 1999 and 2000.

When analysing women's changing role, we must consider some aspects of the area during both the pre-war years and wartime. Friuli was a rural, barely industrialized region, and characterized by a high level of male seasonal migration with 80,000-100,000 men working in the Habsburg Empire and Germany. Mass migration introduced elements of secularization and socialism to this traditionally Catholic society, which, to a certain degree, challenged patriarchalism and, in consequence, strengthened the position of women within families, especially in the foothills and alpine part of the region called Carnia. ${ }^{4}$ As a workforce, women and girls were mainly employed in the countryside, in textile factories, and as servants and housemaids, whilst some of them emigrated abroad and worked in brick kilns. August 1914 had a traumatic effect on the region, as migrants had to return home and the local economy got out of balance. Hunger and unemployment as a consequence of these events led to huge social unrest in 1914/15, in which women were in the 


\section{Proof}

first line protesting against high prices and shortages of goods. Issues such as social and welfare benefits, peace, and neutrality as discussed by the socialist movement also contributed to the uproar, which lasted until March 1915. ${ }^{5}$

From May 1915, the region became a 'war zone', divided into 'operation zones' 10-20 kilometres behind the lines and 'rear areas'. In both these areas military authorities had special powers over civilians. ${ }^{6}$ The rural society in Friuli was considerably transformed by the deployment of 1.5 million Italian soldiers and by 200,000-250,000 workers who came from other regions to build trenches, barns, roads, and railways. ${ }^{7}$ Thus, everyday life, space, time, economy, and relationships were fundamentally changed by militarization. Due to male enlistment, women and children had to cope with the loss of their family income, shortages of essential goods, increasing prices, and inflation. Unprepared for a long-lasting war, the Italian Army exploited the rear area for workforce and raw materials. Within this general framework, the mobilization of society and workforce was implemented, firstly, by the army itself and army organizations such as the 'Segretariato per gli Affari Civili', which took orders directly from the Supreme Command of General Cadorna; secondly, by local authorities (prefetti, mayors); and thirdly, by agrarian institutions and private committees.

The military efficiency of the whole country was closely linked to the economic effort and the capacity to mobilize the civilian population. As Friuli was near the front line the entire society was mobilized in the war effort. While middle- and upper-class women participated in the patriotic effort by joining local committees for work relief and aid to poor people, refugees, soldiers and their families, ${ }^{8}$ lower-class women remained indifferent or even hostile to the war they received with both rage and resignation. Their support of the war agenda was improvised and military authorities, especially in the zone near the front line, initially distrusted the local population and accused them of disloyalty. However, the rear area soon became a resource for workers to fill the gaps of the military logistics effort. Women kept on working in the local textile factories and were involved in farming, where they replaced called-up farmers. In Carnia, on the other hand, the logistic needs of the Italian Army and the scarce agricultural resources attracted women to work for army units behind the front lines. The mobilization of the workforce was conducted to different degrees by military and local authorities. In 1915-16, landowners and mayors sought to encourage peasant women to take up jobs in farm work in order to improve agricultural production. Another type of mobilization was promoted by the state itself and realized by local committees which involved adult women with small children, whose husbands were soldiers, in sewing uniforms and knitting woollen scarves, sweaters, and socks. Between 1915 and 1917, in Udine alone, about 1500 women were employed in this task. It was a form of aid through work, but wages were not sufficient to allow the survival of the families. However, this kind of work was used for propaganda purposes to confirm women's traditional 


\section{Proof}

domestic role. ${ }^{9}$ Women had to fend for themselves and showed great adaptability. During the war, women worked alternatively in the agricultural and the industrial sector, in textile factories, for the army's logistics services and in small businesses. This implied that women, especially young girls, had to move to the interior of the region, and to change their jobs to search for better wages and suitable working conditions.

\section{Women's mobilization in the countryside}

Concern regarding the 'collapse' of agricultural production was common to all rural areas of Italy, as the debates in the Chamber of Deputies illustrate. The situation in Friuli was marked by increasing difficulties, such as a shortage of labour due to enlistment in the army and to the involvement of younger and older male labourers in the logistics effort, as well as infrequent use of farm machinery. From March 1916, the main agrarian association (Associazione Agraria Friulana) urgently advised mayors, priests, and teachers to mobilize the countryside in order to keep up supplies. ${ }^{10}$ It was somewhat of a mass draft: 'The land must not be left abandoned. [...] Behind every army an army of workers is absolutely indispensable [...]. It is therefore necessary that the work of the absent men is replaced by old men, women, and children. ${ }^{\prime 1}$

There are no figures available for this increase in involvement. Nevertheless, during 1916-17 women, young girls, and children replaced men on almost every farm. They performed men's work, such as ploughing, threshing, mowing, fertilizing, driving cars, looking after the cattle, and they had to use machinery for the first time. ${ }^{12}$ Observers pointed out that the work in the fields and stables was taken care of 'entirely by women'. ${ }^{13}$ Local authorities and landowners emphasized that female work required not only 'compensation' but also 'public recognition'; landowners and priests played an important role in mobilizing women. Following the French example, mayors and the Agrarian Association started to award silver medals to peasant women as patriotic symbols of cooperation. In June 1916, the Minister of Agriculture also decided to deliver diplomas, medals, and prize money to peasant women. ${ }^{14}$ In 1917, agricultural production was stimulated through incentives.

These initiatives were accompanied by intensive propaganda: Agrarian bulletins applauded women's new roles and tasks in the countryside and celebrated peasant women within a traditional framework as role models of patriotism and self-sacrifice, sobriety and renouncement. ${ }^{15}$ These articles demonstrated that women could do men's jobs. They were called 'female heroes of the fields' and portrayed as soldiers' mothers or wives who were waiting for their husbands and sons. In the meantime, they looked after house and land, they were attending to housekeeping and farming and in so doing they emulated the soldiers at the front. Rhetorically, the fields became 


\section{Proof}

'battlegrounds', and women were depicted as 'wilful', 'strong', 'energetic', and 'heroic' as they were 'quietly' responding to the 'fatherland's call'. ${ }^{16}$

The first topic that was highlighted by propaganda in 1916 was the notion of 'cooperation'; that is to say, the involvement of women in the national war effort as a 'patriotic duty'. By using dialogic texts and didactic poems which were often written in the local Friulian language to suggest a sort of closeness, propaganda presented women's new roles as recognized and endorsed by God and the nation itself. ${ }^{17}$ Loneliness, separation, and even death of their relatives at the front line became noble reasons for their activities. The second notion was 'stability': stability of production, of gender roles, of families. Even male peasants recognized women's resistance to fatigue, their dedication to the family and to their loved ones at the front as 'patience' and 'obedience'. ${ }^{18}$

Although female labour was not a novelty given women's wartime industrial employment, this development also raised concerns in Friulian society. For that reason, propaganda paid particular attention to gender hierarchy and presented this female work as temporary and exceptional in order to avoid women's masculinization. Photographs depicting women who did 'men's jobs' and used tools and machinery from the 'male world' were not usually published. The few pictures showing women using wagons and machinery presented these tasks as the necessary process of mechanization and the modernization of agricultural production. Abstract and rhetorical ideas were personified and real people shown as examples, such as the 'courageous' Santina Mantovani from Codroipo, mother of eight children, whose husband had been called up and who worked on her own on her large estate. ${ }^{19}$

Due to increasing difficulties, the tone of propaganda changed in 1917. The image of peasant women gradually became militarized. It was used to disseminate the ability to endure suffering, discipline, sobriety, and to rationalize food consumption, ${ }^{20}$ in stark contrast to the image of young urban female workers who were accused of unnecessary spending. ${ }^{21}$ Another propaganda keyword in 1917 was 'strength'. The nation needed 'strong' wives and mothers who would dry their eyes and could cope with mourning and weakness. The increasing atmosphere of resistance and war-weariness among soldiers is well portrayed by a poem, entitled 'Madre Friulana' (Friulian Mother), published by a leading newspaper: A patriotic mother takes her deserter son back to the battlefront. In so doing, she symbolizes every woman's duty. ${ }^{22}$

Local churches contributed to this discourse. In fact, the Archbishop of Udine Anastasio Rossi, who was a patriot, loyally supported the Italian war effort in the official bulletin Rivista diocesana udinese (Journal of the diocese of Udine) between 1915 and 1919. He also played an important role in the representation of women. He mobilized peasant women in public letters, prompted them to subscribe to the national war loan (in January 1916) and accepted that people had to work on Sundays (in April 1916). In February 1917, Rossi asked parish priests to urge congregants to reduce 


\section{Proof}

their consumption: The keyword 'rationing' was associated with the moral issue of 'renunciation' ${ }^{23} \mathrm{~A}$ few months later, he requested them to improve agricultural production. Although parish priests in their diaries underlined the massive work of women and children, labour conditions were not challenged in general, yet nurseries for small children were introduced in almost every village from 1915 onwards to facilitate women's work. ${ }^{24}$ Nevertheless, in 1917 the Catholic authorities started denouncing unnecessary spending and alcoholism among women in the countryside. Furthermore, they condemned defeatism and women who refused to work in order to hasten the end of the war. ${ }^{25}$ In so doing, priests joined the paternalism of civil authorities and landowners who praised only women who sacrificed themselves for their families and the nation. ${ }^{26}$ As had already happened with the demonstrations of 1914, newspapers in 1917 portrayed women protesting against shortages of food and of state benefits as 'imboscati' (slackers) and as being hysterical and irrational. By using a sarcastic tone, articles ridiculed and discredited the unrest. Rural women who stole wood, wheat, and maize were dehumanized and depicted as 'rats'. ${ }^{27}$

All in all, local authorities 'discovered' the female workforce in the countryside during wartime. Their astonishment about women's capabilities was the expression of a deeply bourgeois and patriarchal culture which had confined women to emotional space, devalued female productivity, and feared women's presence in society outside of the private sphere. ${ }^{28}$ For this reason, their work was officially recognized for the first time in special celebrations in village town halls. However, a paternalistic tone prevailed in public discourse, in which women were treated as children who needed to be educated. This public recognition did not improve their everyday lives.

Government and landowners counted on women to accept any hardship in order to make working the land as cheap as possible. Wages $(0.80-1.50$ lire per day, from dawn to dusk) as well as prizes distributed for seasonal work (5-10 lire per woman) remained extremely poor. ${ }^{29}$ Moreover, there were no state benefits for peasants until late 1917.

\section{Beyond propaganda: Linda's and Maria's wartime correspondence}

A close reading of letters that women sent to their relatives at the front allows us to analyse women's changing roles during wartime and to point out their social and cultural meaning. In the following, I refer to letters written by Linda Ellero from Variano, born in 1881 and mother of seven children, to her husband Giuseppe Merlino, a soldier at the front, and those by Maria Nardin from San Vito al Torre, born in 1876, to her father Michele Nardin, who was interned by the Italian Army in Ascoli Piceno. Using the example of these letters, we can learn about the living conditions of peasant women. Both of their families owned and rented small estates of land. Linda Ellero 


\section{Proof}

Women Behind the Lines

21

lived in the Italian rear area, Maria Nardin in the territory that was occupied by the Italian Army in 1915 and very close to the battlefront. ${ }^{30}$

These two women clearly accepted the challenges posed by the war. Their letters show how women had to cope with new tasks. Women became the main labour force along with the young and the old. They had to leave the domestic space (housekeeping, gardening, raising chicken, harvesting fruit) to go outside to the fields to look after the cattle, drive cars, plough, plant, fertilize, harvest, thresh all types of crops, and take care of the vineyards. Both women did 'men's work' and used 'men's tools' (shovels, hoes, sickles, wagons, ploughs), which could also be interpreted in a symbolic way. ${ }^{31}$ They also had to take on new responsibilities on their own, such as managing labour, selling cattle and foodstuff, buying seeds, distributing food rations to eight family members, accounting as well as handling and saving money. In their letters they described their work and what the situation was like in the countryside, complaining about the lack of workforce and the increasing involvement of the elderly and children in agricultural production. Men, on the other hand, were in a state of passivity and helplessness. In spring 1916, for example, Linda Ellero tried to reassure her husband at the front: 'Keep calm Giuseppe, don't worry, neither about us because we're safe, nor about the agricultural work, because if the weather is good, we'll do what we are able to do.'32

Their role implied a new visibility as they attended new spaces such as the marketplace and the town hall. ${ }^{33}$ This involved the establishment of new relationships: Maria Nardin, for instance, had to attend local authorities to sign petitions for her absent father and to obtain benefits: 'Now, dear father, I am always in the town hall, for one thing or another.' ${ }^{34}$ Linda Ellero, on the other hand, often asked the local authorities for leave for her husband and an authorization to visit him at the front, or she had to negotiate requisitions of cattle with military officials. Their relationship with state and local authorities was characterized by diffidence and submissiveness, but also by anger and the determination to fight for their rights.

Both women were in a state of constant nervousness and tension due to the war. They faced the new situation courageously, yet with feelings of uncertainty. Occasionally, when they were not sure about how to handle a certain situation, they discussed the problem with husband or father, asked for their permission to decide or took decisions together with them. Relatives tried to give suggestions and advice, yet these women, who were well aware of the local situation, acted on their own and proudly claimed their independent choices: 'So, if I had followed uncle's decisions, I would have done bad business, then, dear father, I did it all on my own, I didn't ask anyone, I want to do it by myself. ${ }^{35}$ This new kind of female attitude and behaviour pattern can't be stressed enough, all the more given the fact that everyday life in the rear area was hard, a 'bad life', 'full of sorrow and worries', as these two women wrote. ${ }^{36}$ Women sometimes confessed weakness and increasing fatigue, sometimes they felt powerless and inadequate, especially because 


\section{Proof}

of the double workload of family and outside work. In October 1916, Linda Ellero wrote: 'To tell you the truth, dear husband, I haven't got enough breath to thank God for giving me and the children health, as we had to work the whole season. ${ }^{37}$ Maria Nardin, too, grieved and declared her weakness. She wrote in June 1917: 'Dear father, if you knew what my head is like... a drunk's is better than mine. ${ }^{38}$ Sometimes both women were so lonely, tired, and confused that they wanted to give up making decisions. However, they were also happy to tell about their decisions, and proudly claimed their increasing business skills. ${ }^{39}$ Female behaviour patterns were characterized by a progressive awareness and growing empowerment, yet always accompanied by uncertainty and the continuous search for male approval. This is shown by the fact that both women in their letters of 1917 devoted increasing space to their personal feelings, yet mentioned farm matters less frequently because women's work tasks ceased to be extraordinary. As we have seen, the years 1915 and 1916 were marked by significant changes in women's lives.

The letters also underline the transformation of the rural landscape brought about by the war. In October 1915, Maria Nardin wrote that soldiers had dug trenches in the fields and cut trees, while cars and trucks were passing by. She was not allowed on the fields, soldiers examined passports at military checkpoints and officers banned the cutting of the corn. ${ }^{40}$ Maria witnessed damage, destruction of crops, and also thefts by soldiers. Furthermore, air raids were a source of constant fear. ${ }^{41}$ Linda Ellero, in contrast, who lived in an area far away from the front line, experienced the repercussions of the war in terms of labour shortage, enlistment of men from the village, requisitions of cattle, and widespread diseases. In this context they both stressed the deterioration of living conditions, the fragile economy, and the increasing difficulty in finding food. Due to the war both became 'single women': In August 1917, Maria Nardin's interned husband died of tuberculosis in Maribor, and her father, Michele Nardin, did not return from Ascoli until 1919. Linda Ellero lost her husband Giuseppe Merlino who, in September 1917, died at the front of a disease. These circumstances were not uncommon.

Our two examples show how peasant women, who did not necessarily identify with the official war aims or war motives, experienced problems concerning working conditions. Moreover, the war had an intense, existential impact on them. Their main intention was to keep their families together, and their choices were not in accordance with the submissive image of women portrayed by public discourse. They were neither involved in the rhetoric of war, nor matres dolorosae. In fact, they tried to take a step across gender roles and acquired a new identity. The tensions they experienced were reworked within the family, as shown by numerous examples in 1917, when other women, who perceived the injustices brought by war, decided to protest publicly and to protect deserters, challenging the strong repressive police apparatus behind the front. ${ }^{42}$ 


\section{Proof}

Women Behind the Lines

\section{Behind the front lines}

Another form of wartime mobilization of women and girls was their employment in war logistics. This occurred especially in Carnia, in the rear of the Alpine part of the front, where people were involved in building military installations from the autumn of 1915 onwards. The villages' close vicinity to the front line as well as the lack of roads and infrastructure were reasons for many to participate. While young people and non-fighting men were recruited for the construction of roads, trenches, barracks, and military stores, women and girls were employed as 'portatrici' (see Figures 2.1-2.3) to transport tools and goods to the soldiers in the trenches up in the mountains. ${ }^{43}$

Mobilization of the female workforce intensified when even young girls aged 11 to 12 and elderly women aged 50 to 60 were recruited. In February 1916, about 1600 women in Carnia worked for the Italian Army (45 per cent of all troops at the Carnian front line), while in summer 1917, 4000 women were employed (33 per cent). ${ }^{44}$ As male migration ceased in 1914/15, work for military units in addition to state welfare benefits and income from gardening was the only way to survive. Women were directly recruited by officers and had to transport food, cognac, pasta, wood, barbed wire, and ammunition in large baskets on their backs towards the lines. While ascending altitudes from 500 to 1000 metres along alpine paths, they were often

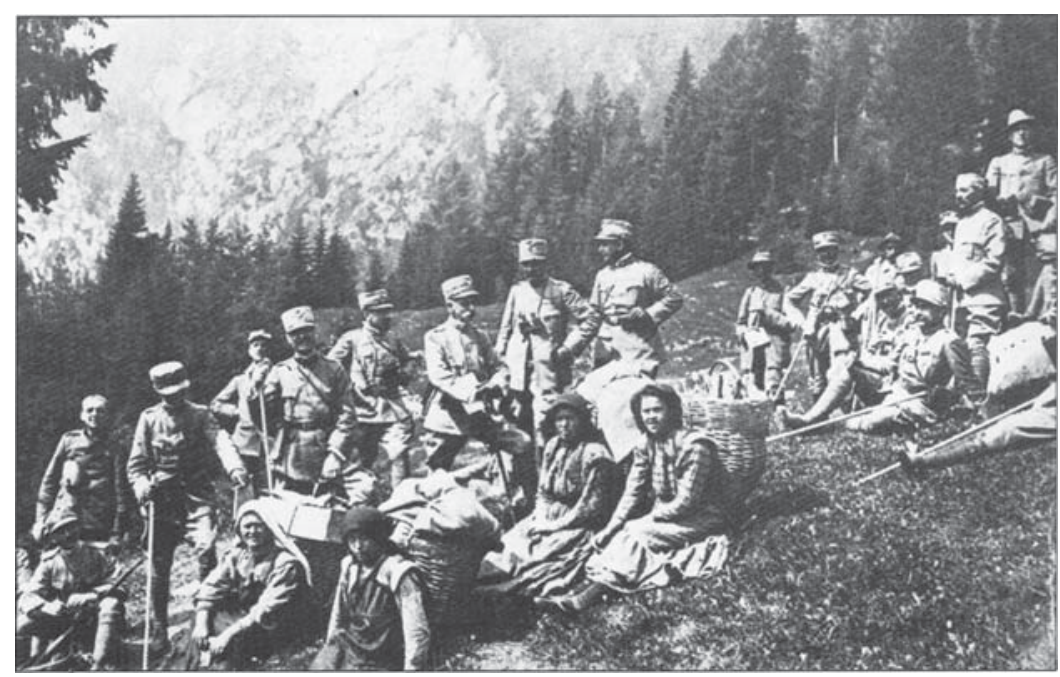

Figure 2.1 Inspection of the Alpine post Timau (Zona Carnia - But alto). In the middle are Generals Segato, Airoldi, and Fara with portatrici and troops around them Source: Museo della Guerra di Timau (Udine). 


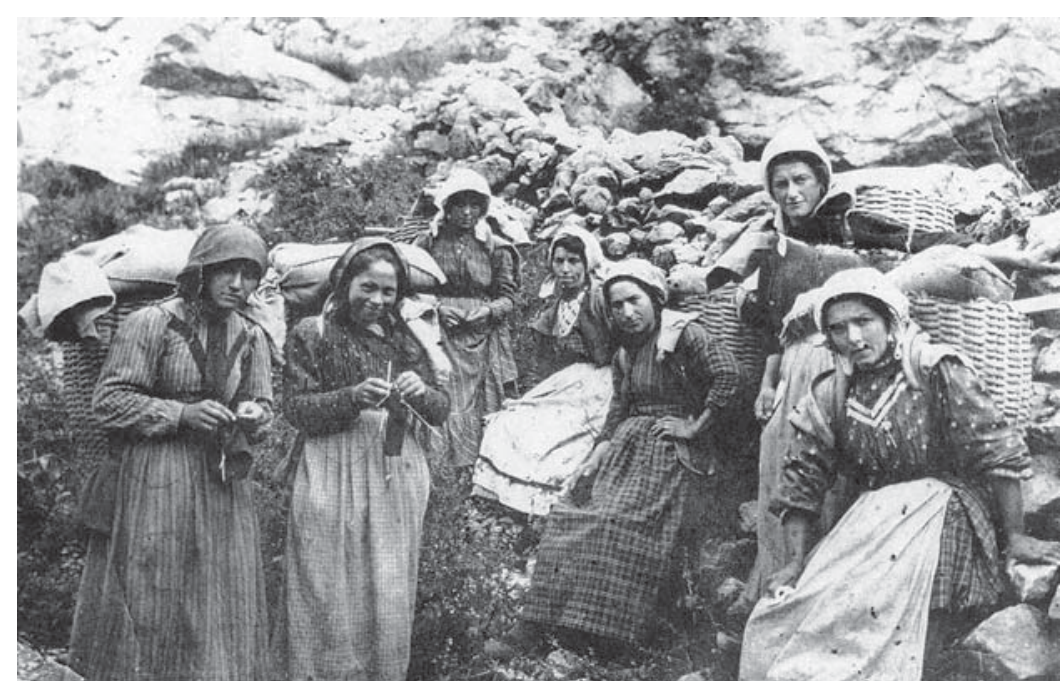

Figure 2.2 Portatrici of Paluzza

Source: Museo della Guerra di Timau (Udine).

exposed to enemy fire. They arrived at the military barracks after walks of two or three hours and then went back to their homes. The pay for each trip was 2.50 lire. The goods they carried weighed between 35 and 50 kilogrammes. The portatrici worked in all weather conditions and also under enemy fire. The case of Maria Plozner Mentil from Paluzza, for instance, is well known; she was shot dead in February 1916 by a sniper while she was transporting food for soldiers. Maria Vigezza from Moggio Udinese, aged 48, died on 18 November 1916 when a bomb was dropped by an Austrian airplane while she was delivering gravel. ${ }^{45}$

General Agostino D'Adamo, chief of the Segretariato Generale per gli Affari Civili, tried to regulate women's employment in military units and protect them from exploitation and excessive risks. On 11 January 1917, he issued a decree that banned the enlistment of women younger than 17 and older than 50 years. These women could not be forced to work in areas 'under enemy shell fire' or do heavy or dangerous work; their wages ranged from 2.50 to 4.00 lire for a ten-hour working day. They were not subjected to the code of military justice, yet lack of discipline and absence without notice were punished with fines and wage deductions. Women were to be recruited in the villages near the front line and were supposed to go back home every day; meals and lodging were provided only if the women worked in isolated places near the front line. However, these regulations were not acknowledged in Carnia. Local army officers refused to dismiss young girls arguing 


\section{Proof}

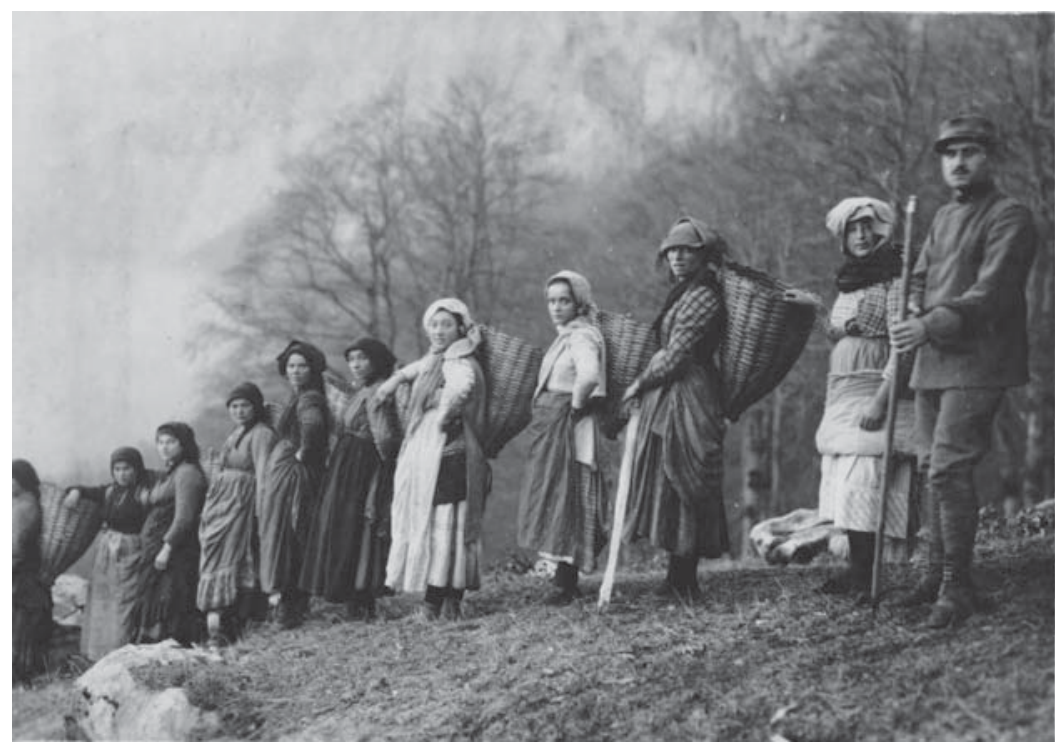

Figure 2.3 Carnic portatrici on a souvenir photograph

Source: Museo Centrale del Risorgimento, Rome, Album O2, 7.32.

that their exclusion would reduce the workforce and push the girls 'into prostitution' because they were not under the control of their fathers. ${ }^{46}$

Poorly paid, this female work was considered mainly as a form of support for army units. As interviews revealed, it was perceived as an extension of traditional jobs held in the mountain estates such as transporting hay or alpine pasture. In the interviews, the women emphasized the danger they faced and the heavy fatigue they experienced. 'Fatigued to death', as Irma Casanova, one of the last survivors, told me in 1999. In fact, during the winter, women had to transport goods in high snow and they had to shovel paths and roads. Their work started early in the morning and at times went on overnight to avoid being discovered and shot. They remembered that they were terrified by artillery fire whilst hauling supplies. ${ }^{47}$

Women therefore had to bear a great burden during wartime: logistic work, farming, mothering, and housekeeping. It is difficult to decide if these women were motivated to work for patriotic reasons; they accepted their mobilization as a duty, but also as a relief from poverty. They often expressed their solidarity and grief for the soldiers who had to live, suffer, and die in the trenches. All in all, their relationship with the military was ambivalent as on the one hand they received food and cigarettes from the soldiers, on the other they were severely controlled by the officers. Especially in the first phase of the war, military units were harsh, because they suspected civilians who lived near the 


\section{Proof}

borderline to be spies or enemies. From this perspective, women's work can also be seen as a sort of demonstration of loyalty. Often officers used women's and girls' fear of the enemy to force them to work. In some cases the military brutally requisitioned women, even those pregnant, to tow artillery or shovel snow from alpine roads. ${ }^{48}$

The third year of the war was characterized by a crucial transformation of women's role in the Alpine rear areas. When the army built cableways to transport goods and ammunition to the highest front lines, women were employed to keep roads clear of snow or to transport gravel to maintain roads. Due to the shortage of male workers during spring and summer 1917, women and even girls were employed in heavy labour such as mining, excavating trenches and building roads and railways. This implied medium and short-scale migration to other valleys or towards the military workshops behind the Isonzo front. Work in the rear areas became dirty, heavy, and dangerous; women cut their fingers, got grit in their eyes, fell over and broke their limbs, or had frostbites. Some of them died or were heavily injured by exploding mines or in accidents. ${ }^{49}$ It is very difficult to know how many women were injured, killed, or fell ill, not only because these cases were subject to censorship, but also because women were excluded from benefits such as those given to disabled ex-servicemen and were reserved for male military workers. Few disapproved of the harsh conditions for women. In June 1917, labour inspector Guido Picotti wrote to General D'Adamo that in the yards of Carnia there was 'no military control' of recruitment and officers tried to 'avoid providing tents and beds for the workers'. Picotti criticized 'precarious sanitary conditions, widespread involvement of children, youths, and women without the respect of any law'.50

This complaint remained a dead letter. The main problem as perceived by local authorities was women's morality. In fact, in October 1917, the Friulian Catholic deputy Michele Gortani deplored the perils of prostitution among young female workers of Carnia and was worried about the 'honesty' and 'innocence' of married women and children. ${ }^{51}$ Similarly, priests of the villages in Carnia described women's deep involvement in military work in their parish books. They did not mention anything about women's 'masculinization' as, due to male migration, women in alpine regions had already been used to hard labour before the war. What bothered priests was that female liberty emphasized 'male' patterns of behaviour such as personal autonomy, lack of control, and absence of family restraints, especially among the young female generation.

Nevertheless, women cooperated with the army and their work allowed the troops to protect the high-lying trenches. In some places at the front in Carnia (Timau, Paluzza Paularo), the transport of supplies and road maintenance was almost entirely conducted by women. Despite their massive involvement, women employed in the army units were neither recognized nor praised as peasant women were. Reports of their work were censored and 


\section{Proof}

Women Behind the Lines

withheld from public discourse - perhaps to avoid criticism from enemy propaganda, perhaps because it was too heavy, too dangerous, and too 'male'. In fact, women were dangerously invading 'masculine' spaces such as trenches and the war zone, and they approached 'male' jobs par excellence: they were 'making war'. At the same time, this kind of women's work was often accompanied by promiscuity and for this reason was suppressed in public discourse: No article described their heavy work, no photograph was published on this subject. Consequently, propaganda rather chose to glorify a reassuring image of peasant women.

\section{Women without men and men without women}

Behind the front, Friulian rural communities had to deal with a large presence of soldiers who, on the one hand, stimulated commerce with civilians, yet on the other transformed mentalities and social mores. In this new 'wartime society', women played an important role and were submitted to severe tensions. Faced with inadequate benefits and increasing prices, women had to leave their homes and earn money. They became street vendors, worked as shop assistants, opened inns, rented out rooms to soldiers and officers, cooked meals, sewed, washed and ironed military clothes, or worked in logistics and workshops. They were paid small sums of money, food, or clothes. ${ }^{52}$ Due to the forced absence of men, communities, and families were shaken and the war destroyed traditional rules of community and gender relations. Young girls experimented with new and more open relationships with soldiers and officers, while the stability of marriages was jeopardized by free relationships ('unioni libere') between married women and soldiers. These were characterized by a mutual search for understanding and comfort in view of personal vulnerability and fragility during the war. While men were looking for rest, leisure, and a 'normal life' far from the trenches, women recognized the soldiers' fragile condition and welcomed them as sons, brothers, or husbands. Women escaped from uncertainty and isolation in these relationships, which were also instrumental in improving their quality of life given the worsening living conditions. ${ }^{53}$

Parish priests condemned the 'moral decay' and accused women and girls of immorality, crime, inadequate parental control, bad language, provocative fashion styles, and, above all, sexual relationships with soldiers. Priests were worried because this new behaviour threatened to weaken faith and the moral authority of the Church among peasants. ${ }^{54}$ In June and again in December 1916, the Archbishop of Udine, Anastasio Rossi, repeatedly denounced the 'painful consequences' of the soldiers' presence in rural communities because of the number of 'illegitimate babies, broken engagements, and abandoned women'. ${ }^{55}$

Yet there was another side to these new forms of relationships and lifestyle. The amount of rape and clandestine prostitution due to poverty and hardship 


\section{Proof}

rose significantly. So many mothers and young servants became occasional prostitutes that venereal diseases were widespread and the army was forced to establish military brothels to prevent diseases among troops. ${ }^{56}$ In fact, the province of Udine was the one with the highest rate of illegitimate babies from Italian or, in 1917/18, Austro-German soldiers. Birth ratio increased in the years 1915-18 from 359 to 836 (per 10,000). ${ }^{57}$ In Mortegliano, for instance, a typical rural village of the lowlands with 3400 inhabitants, there were about 25 illegitimate births between 1915 and 1918, instead of the two or three cases per year in the pre-war period. ${ }^{58}$

Surveys in newspapers and parish books demonstrate that prostitution was not considered as a result of increasing poverty, but as women's desire for 'lust and pleasure', evasion of parental control, and scarce maternal education. However, the 'liberalization' of sexual mores did not constitute women's emancipation. Though there was greater freedom in sexual relationships, there was also a large increase in rape and prostitution. During wartime this behaviour became 'ordinary', due to the fact that people were living in an 'extraordinary' period, in which all social and moral restraints fell and adaptation prevailed. Illegitimate births meant severe problems for girls and women, as they were often marginalized by their families and communities. This resulted in a growing infant mortality rate, due to neglect, abortion, and infanticide.

Concern about social mores and girls' independence was also fed by an increasing juvenile mobility in 1917. As mentioned previously, the shortage of male workers stimulated migration from the mountains and the countryside to military workshops at the Isonzo front, where women produced masks, mats, and coverings for trenches, and mended used uniforms. This weakened parental restrictions and enhanced personal and economic independence. The new situation was perceived as a social threat in as much as women and juvenile workers were seen as criminals or 'irregular' subjects, who jeopardized not only traditional hierarchies between upper and lower classes, but also between the sexes. ${ }^{59}$ Female workers and peasant girls were accused of wasting their money on superfluous expenses, such as wine, new clothes, short skirts, stockings. In addition, they were reproached for new behaviours, such as 'male' language, hedonism, provocative clothes, 'immorality', and the lack of religious feeling.

In this context, newspapers condemned promiscuity at the workplace and saw women and young girls as potential prostitutes and as elements of disorder and 'immorality'. Civil and Catholic authorities, on the other hand, wished to maintain, and even to cultivate and glorify, traditional 'feminine' qualities, especially women's maternal 'instincts' towards sons and husbands at the front. Moral and social concerns were used to justify a new repressive wave in rear areas and in the city of Udine during the summer of 1917. Military records show that the arrests of women were often based on anti-female stereotypes such as bad moral behaviour ('cattiva condotta morale'), occasional 


\section{Proof}

prostitution, and poverty, and were aimed at assuring social and political control in order to prevent unrest behind the front. ${ }^{60}$

\section{Celebrating a 'sad victory': final remarks}

The defeat at Caporetto in October 1917 marked a rupture in the involvement of civilians in the war. About 135,000 people, mostly women and children, fled from Friuli towards other Italian regions, while 500,000 remained under enemy occupation. These events had severe effects on women and on women's public image, which turned women from active participants in the war effort into passive bystanders, from heroines into victims of war. Women who fled the area were depicted as patriotic refugees who escaped 'Teutonic slavery', while women who remained in the occupied territories were represented as having fallen victim to rape by the 'barbarian enemy'. In this understanding, women stood as a symbol for 'the body of the nation'. Both patterns were used to bolster soldiers' resistance at the River Piave battlefront until the end of the war and also to portray the nation as welcoming towards refugees. ${ }^{6}$

After the war, the female image shifted to the 'mourning mother'. In the 1921 celebrations of the 'unknown soldier', in Udine, Gorizia, and Aquileia, women were again considered only as 'soldiers' mothers' or 'soldiers' wives', and depicted as heroic victims who represented the national mourning. The main image was the Catholic mater dolorosa or the war widow, which stressed women's domestic and maternal roles and their willingness to sacrifice their husbands and sons for the nation. ${ }^{62}$ These ruling class and gender models and the representations of mourning were unacceptable for peasant women. Despite the visibility they had gained as workers, this role was neither recognized nor recalled in public discourse. Female experiences were excluded and women did not find adequate channels to express themselves and their suffering, also due to the fact that even the socialist party in the post-war years supported only returning soldiers. ${ }^{63}$ The 'other side of the war' remained hidden in diaries or in letters. These traces of women's experiences were almost completely neglected, overshadowed by the myth of victory and the 'male' nation at war. Fascism later on ideologically reinforced this process by increasing the emphasis on gender differences. ${ }^{64}$

It was not until 1969 that finally state authorities officially awarded the honour of Cavaliere di Vittorio Veneto, to the portatrici carniche as a symbol of women's patriotism, maybe because this specific and extreme mobilization could be linked to the soldiers in the trenches. In 1997, Italian president Oscar Luigi Scalfaro rewarded the 'heroine' Maria Plozner Mentil with the gold medal for military valour. ${ }^{65}$

In Friuli, 4 November 1918 was a day of liberation rather than a day of victory. Here, in the 'liberated territories', people celebrated a quasi 'sad victory'. The main issues of 1919 were mourning, reconstruction, but also 


\section{Proof}

anger and a desire for social change. The return of refugees and men from the battlefront and the process of reconstruction were traumatic due to devastation, losses, hunger, and disease. About 15,000 soldiers and 5000 civilians had died during the war, thousands came back injured, sick, and wounded. Women had to bear a large part of the burden by caring for men and children.

The war experience can be described as complex and contradictory. Friulian women faced 'total war' and they, too, were directly affected by the violent face of war in this border region, while they were gaining 'liberation' and 'emancipation' to a significant extent. For them, the experience of war meant fatigue, social upheaval, insecurity, fear, diseases, hardships, dislocation, violence, humiliation, and anger. As diaries and letters demonstrate, they were concerned with responsibility for their family and relatives, strain, and loss rather than with patriotic duties. However, despite the militarization of society, hardships, and war violence, women handled their duties very well. In so doing, they surprised civil and military authorities with their ability to undertake heavy work and with their efficiency, both behind the front and in the countryside. Due to women's farming, agricultural production in Friuli was maintained at almost pre-war levels, while the work in the rear area allowed Italian troops to stay in the mountain trenches for three years.

War shook up gender relations, yet only temporarily, especially in rural communities where sexual and gender hierarchies were more stable. Although women's work became more and more important, this process developed within a framework which was still characterized by subordination and devaluation and in which women were still treated as inferior. In public discourse, the war was represented as a 'male war'. Until October 1917, official propaganda emphasized traditional images of women to reassure the stability of gender roles. In addition, some inconvenient facts such as the presence of women at the front line were hidden. Women's work, although effective in boosting the war effort, was considered as temporary almost everywhere. Gender stereotypes were maintained rather than challenged. Military authoritarianism, paternalism, and patriarchalism as well as religious and moral rules preserved and stabilized gender roles. Local and military authorities considered women's work as a 'natural' duty. In so doing, they reinforced the subalternity of women's position in society and contributed to keeping wages to a minimum: In fact, women's wages, routinely portrayed as 'high' in the wartime press, remained significantly lower than male wages. Working in the mountains with military units and sewing uniforms for the soldiers were considered as forms of assistance rather than as 'proper' jobs like men's work. Women's employment and payment were merely to avoid poverty and prostitution. Moreover, the fact that many female jobs were closely linked to the 'war' itself made it necessary to emphasize their being exceptional and temporary, yet also affected the process of emancipation through work negatively and turned into mass exploitation. In some cases, women's labour 


\section{Proof}

Women Behind the Lines

31

was viewed as too extreme and, paradoxically, as exceptional rather than as a starting point for emancipation. Overall, the priority given to 'moral' issues, which actually hid any fear of the subversion of gender and class hierarchy, prevailed over labour safeguards. Therefore, women in 1919 considered the end of the war as a relief and a return to 'normality'.

The issue of the troops' homecoming has yet to be fully investigated. We need further research on the early 1920s: Beyond the myth of victory, local sources such as parish reports reveal that violence, hunger, and prostitution characterized the post-war years until $1923 .{ }^{66}$ The post-war experience was not free of pain, as high mortality rates, the collapse of marriages, the decline of births, and a growing number of separations show. In the aftermath of the war, new social subjects emerged such as war widows, who had to manage their estates on their own and tried to enter extra-marital relationships ('more uxorio'), as they would have lost their benefits in the event of remarriage. ${ }^{67}$

Although they were reliable and capable, women's 'citizenship' was still considered second class, as the state denied them both the right to vote and special welfare benefits. Public space became narrower in the post-war years, while the private sphere assumed new importance. Nevertheless, during the war women reasserted their position in their families and gained more confidence in their own abilities by demonstrating courage and responsibility. The war only accelerated the ongoing social process of emancipation which had already been initiated by migration. 'Wartime skills' such as self-confidence, autonomy, mobility, the ability to adapt to different tasks were not lost, but could be applied again during the great depression after 1929 and the Nazi occupation between 1943 and 1945. Furthermore, women were more familiar with their role in society and multiplied their relationships with state and local authorities. Those who had experienced mobilization and evacuation developed a sense of citizenship and were well aware of the new rights they had acquired by having contributed to the war effort. These feelings became apparent especially in April and June 1919, when women protested against food shortages and high prices. In this way, the war diminished traditional paternalism between upper and lower classes. Social inequalities, the national war effort, flight, and occupation contributed to making women aware of their rights within society. They became even more inspired and radicalized by the example of revolutionary Russia.

In a generational perspective, the Great War constituted a turning point. This is true in particular for younger women and girls, who attained more autonomy and found their wartime labour experiences in some way 'liberating' because they were able to escape from parental restraints and experienced new patterns of socialization. This critical step was characterized by severe instability and war violence, factors that made this wartime 'transformation' even more remarkable. Even though women's social status did not change permanently in the short term, wartime experience eased the distance between male and female worlds in the long run. 


\section{Proof}

\section{Notes}

1. In this chapter I refer to the former 'Provincia di Udine' that belonged to the Veneto region as Friuli.

2. On 25 October 1917, the Austro-German army under General von Below achieved a significant breakthrough by a gas attack against the weak Italian lines in the Isonzo valley near the little village of Caporetto. German and Austrian forces penetrated into Friuli and conquered Udine. They captured 300,000 soldiers, and occupied Friuli and part of the Veneto region within a week. In order to avoid a wide encirclement of the armies placed along the main line of the Carso front, General Cadorna ordered a retreat to the right bank of the River Piave. The Caporetto defeat became somewhat of a 'stain' on the Italian First World War campaign. During the retreat, Cadorna accused his soldiers of cowardice and interpreted the defeat as a soldiers' strike. Although the events of Caporetto were actually due to a military strategic surprise, the defeat became a symbol in public discourse of the 1917 Italian crisis both at the front line and at the home front, and contributed to the repression of and suspicion against 'internal enemies'. Among the broad range of publications, see N. Labanca, G. Procacci and L. Tomassini (1997) Caporetto: Esercito, stato, società (Florence: Giunti); N. Labanca (1997) Caporetto: Storia di una disfatta (Florence: Giunti).

3. Italian historiography has analysed the situation of women especially in industrial towns (Turin, Milan, Genoa), while research on women from rural districts has been sparse. Since the 1980s, women's industrial work has been selected as a paradigm to analyse women's changing roles, and this approach has affected the understanding of women's wartime experience as a whole. In the late 1990s, historians started to investigate the First World War as a 'total war' and tried to evaluate the impact of war on society behind the front line. See M. Ermacora (2007) 'Le donne italiane nella Grande Guerra: Un bilancio storiografico (1990-2005)', in P. Antolini, G. Barth-Scalmani, M. Ermacora, N. Fontana, D. Leoni, P. Malni and A. Pisetti (eds) Donne in guerra, 1915-1918: La Grande Guerra attraverso l'analisi e le testimonianze di una terra di confine (Rovereto: Centro studi Judicaria, Museo storico italiano della guerra), pp. 11-30.

4. See L. Lorenzetti and R. Merzario (2005) Il fuoco acceso: Famiglie e migrazioni alpine nell'Italia d'età moderna (Roma: Donzelli).

5. See M. Ermacora (2001) Un anno difficile: Buja tra pace e guerra (agosto 1914maggio 1915) (Udine: El Tomàt); E. Ellero (2007) Friuli 1914-1917: Neutralità, guerra, sfollamenti coatti, internamenti (Pasian di Prato: Ifsml), pp. 19-61.

6. N. Labanca (2008) 'Zona di guerra', in M. Isnenghi and D. Ceschin (eds) La Grande Guerra: Uomini e luoghi del '15-'18, vol. 2 (Turin: Utet), p. 606.

7. See M. Ermacora (2005) Cantieri di guerra: Il lavoro dei civili nelle retrovie del fronte italiano (1915-1918) (Bologna: Il Mulino).

8. See D. Menozzi, G. Procacci and S. Soldani (2010) Un paese in guerra: La mobilitazione civile in Italia (1914-1918) (Milan: Unicopli).

9. See 'Commissariato Generale per l'assistenza civile e la propaganda interna' (1917), in Notizie 23 sull'Assistenza civile in Italia al 30 giugno 1916 (Rome: Bertero), p. 54.

10. 'Agricoltura di Guerra', L'Amico del Contadino, 15 January 1916, p. 2.

11. Associazione Agraria Friulana, 'Collaborazione delle donne friulane nel lavoro dei campi', 28 March 1916, Archivio di stato di Udine, Archivio della deputazione provinciale, b. $808, \mathrm{I} 56$.

12. A. Roja a don P. Valle, 29 May 1917, Archivio Roja, Tolmezzo, b. 149. 


\section{Proof}

Women Behind the Lines

13. G. Bubba (1916) 'Il lavoro delle donne nell'alto Friuli', L'Amico del Contadino, 7 October, p. 3.

14. 'Premi di produzione per incoraggiare la collaborazione delle donne al lavoro nei campi', L'Amico del Contadino, 17 June 1916, p. 3.

15. 'Anute, tu as alvorât par doi!' [Ann, you did the work of two !], L'Amico del Contadino, 1 July 1916, p. 4.

16. Quotes from: 'Le donne italiane che sostituiscono i combattenti devono essere additate a pubblica riconoscenza', L'Amico del Contadino, published between August and November 1916.

17. See 'Il lavôr das feminis' [Women's work], L'Amico del Contadino, 3 September 1916, p. 2; A. Molinari (2008) Donne e ruoli femminili nell'Italia della Grande Guerra (Milan: Selene Edizioni).

18. 'Lis feminis. Discors tra Tite e Toni' [Women: Dialogue between Giobatta and Antonio], L'Amico del Contadino, 23 September 1916, p. 4.

19. 'Il premio del Ministero dell'Agricoltura alle lavoratrici dei cereali', Il Corriere del Friuli, 1 July 1917, p. 2.

20. See, for example, 'Cucina di guerra', L'Amico del Contadino, 25 February 1917, p. 3.

21. 'Pes femines. Fat di veretât' [For women. True facts], L'Amico del Contadino, 30 December 1916, p. 2.

22. 'Le donne e la guerra', La Patria del Friuli, 11 June 1917, p. 3.

23. A. Rossi (1917) 'Lettera pastorale', Rivista diocesana udinese, 24 February, pp. 61-77.

24. For example, see: Libro storico parrocchiale di Fagagna [Historical parish book], sub 15 June 1916, p. 11.

25. 'Dicerie sciocche e perniciose', L'Amico del Contadino, 2 June 1917, p. 1.

26. See, for example, 'Le donne forti', Il Corriere del Friuli, 10 July 1917, p. 5.

27. See, for example, 'Tavagnacco. Le donne agitate', La Patria del Friuli, 1 February 1917, p. 3; 'Tricesimo. Una donna granivora', La Patria del Friuli, 4 February 1917, p. 2.

28. See B. Pisa (2011) 'L'évolution de l'identité féminine en Italie au cours de la Grande Guerre', in F. Bouloc, R. Cazals and A. Loez (eds) Identités troublées, 1914-1918: Les appartenances sociales et nationales à l'épreuve de la guerre (Toulouse: Editions Privat), p. 271.

29. These figures are taken from: 'Fagagna, Le donne premiate dal ministero dell'agricoltura', La Patria del Friuli, 7 July 1917, p. 5.

30. Linda Ellero and Giuseppe Merlino's correspondance is published by G. Sut (1998) Torno o non torno: Giuseppe Merlino fante friulano e la grande guerra da lui non voluta (Pordenone: Edizioni Biblioteca dell'Immagine); Maria Nardin's letters are published in C. Mengozzi (2006) Raccontare la Grande Guerra: Lettura di un epistolario di San Vito al Torre (Mariano: Circolo Comunale di Cultura).

31. See L. Scaraffia (1988) 'Essere uomo, essere donna', in P. Melograni (ed.) La famiglia italiana dall'Ottocento ad oggi (Bologna: Il Mulino), p. 196.

32. Linda Ellero to Giuseppe Merlino, 28 March 1916, in Sut, Torno o non torno, p. 49.

33. Linda Ellero to Giuseppe Merlino, 4 December 1916, in Sut, Torno o non torno, pp. 141-2.

34. Maria Nardin to Michele Nardin, 18 January 1916, in Mengozzi, Raccontare la Grande Guerra, p. 168.

35. Maria Nardin to Michele Nardin, 24 May 1917, in Mengozzi, Raccontare la Grande Guerra, p. 207.

36. Linda Ellero to Giuseppe Merlino, 11 October 1916, in Sut, Torno o non torno, p. 111; Maria Nardin to Michele Nardin, 18 January 1916, in Mengozzi, Raccontare la Grande Guerra, p. 168. 


\section{Proof}

37. Linda Ellero to Giuseppe Merlino, 11 October 1916, in Sut, Torno o non torno, pp. 111-12.

38. Maria Nardin to Michele Nardin, 14 June 1917, in Mengozzi, Raccontare la Grande Guerra, p. 207.

39. Sometimes they downplayed their satisfaction in their work due to the absence of their male relatives, whom they missed. In June 1916, Linda Ellero wrote: 'The countryside's good enough. Well, but being unhappy, anything can be appreciated.' Linda Ellero to Giuseppe Merlino, 12 June 1916, in Sut, Torno o non torno, p. 63. At the end of 1916, Giuseppe Merlino was concerned about her health and wrote: 'I'm surprised, dear wife, [...] but I wish you didn't have to work so much because, dear wife, if you don't finish today, you'll do it tomorrow. I know that when things are done it's better, but you don't have to die for it.' Giuseppe Merlino to Linda Ellero, 20 October 1916, in Sut, Torno o non torno, p. 116.

40. Maria Nardin to Michele Nardin, 24 October 1915, in Mengozzi, Raccontare la Grande Guerra, pp. 163-4; about military bans, see also 6 February 1916, p. 169.

41. Maria Nardin to Michele Nardin, 4 April 1916, in Mengozzi, Raccontare la Grande Guerra, p. 176.

42. See G. Procacci (1991) 'La protesta delle donne delle campagne in tempo di guerra (1915-1918)', Annali dell'Istituto Alcide Cervi, 13, pp. 57-86.

43. This kind of mobilization was common in the Alpine rear areas of the front (Carnia, Cadore, Altipiano di Asiago). Between 1915 and 1917 the Italian army employed about 12,000 female workers in logistic tasks. See M. Ermacora, Cantieri di guerra.

44. Minuta gen. D'Adamo, Archivio Centrale dello Stato, Roma (hereafter ACS), Segretariato Generale per gli Affari Civili (SGAC), b. 483.

45. Vigezza Maria, 18 November 1916, ACS SGAC, b. 695; Archivio comunale di Paluzza, b. 770, fasc. Guerra 1915-1918: Pensioni ai civili. The village of Paluzza was characterized by a shocking death toll amongst civilian workers.

46. ACS SGAC, b. 483, fasc. Mano d'opera femminile: Comando Supremo - SGAC, 11 gennaio 1917, n. 110457; ACS SGAC, b. 483, fasc. 26. For the officers' refusal, ACS SGAC, Zona Carnia, Comando genio militare XII C.d. A., a SGAC, n.5321, 16 February 1917.

47. M. Ermacora (2000) 'Il lavoro dei ragazzi friulani dall'età giolittiana alla Grande Guerra', in B. Bianchi and A. Lotto (eds) Lavoro ed emigrazione minorile dall'Unità alla Grande Guerra (Venice: Ateneo Veneto), pp. 132-4.

48. See Libri storici parrocchiali di Paularo (sub 1915), and Monaio (sub 1915, p. 18).

49. The records of Segretariato Generale per gli Affari Civili provide a lot of cases of injuries and diseases; see, for example, ACS SGAC, b. 685, 688, 689, 692.

50. ACS SGAC, b. 508, Picotti a Comando Genio Zona Carnia, 24 June 1917.

51. Atti Parlamentari, 24th leg., 18 October 1917, p. 14621.

52. See L. Fabi (2000) 'Militari e civili nel Friuli della Grande Guerra prima di Caporetto', in G. Corni (ed.) Il Friuli, Storia e società, 1914-1925 (Pasian di Prato: Ifsml), pp. 125-42.

53. For this 'mass mothering', see C. Fragiacomo (1990) 'Paularo. Un paese in guerra', in L. Fabi (ed.) La gente e la guerra, vol. 1 (Udine: Il Campo), pp. 157-88.

54. See Libro storico parrocchiale di Avasinis, 11 March 1917.

55. A. Scottà (1991) I vescovi veneti e la S. Sede 1915-1918, vol. 2 (Roma: Edizioni di storia e letteratura), p. 523.

56. See E. Franzina (1999) Casini di guerra: Il tempo libero dalla trincea e i postriboli militari nel primo conflitto mondiale (Udine: Gaspari). 


\section{Proof}

Women Behind the Lines

57. L. Livi (1921) 'La natalità illegittima durante la guerra', Rivista internazionale di scienze sociali e disciplina ausiliarie, 91, pp. 145-55.

58. Archivio Curia Arcivescovile di Udine (hereafter: ACAU), Visite pastorali, Mortegliano, 1923.

59. See B. Bianchi (1995) Crescere in tempo di guerra: Il lavoro e la protesta dei ragazzi in Italia 1915-1918 (Venice: Cafoscarina); M. Ermacora, 'Il lavoro dei ragazzi friulani', pp. 50 and 64 .

60. See M. Ermacora (2007) 'Le donne internate in Italia durante la Grande Guerra: Esperienze, scritture, memorie', DEP. Deportate, esuli, profughe. Rivista telematica sulla memoria femminile, 7, pp. 1-27, available online at: www.unive.it/dep.

61. See D. Ceschin (2006) Gli esuli di Caporetto: I profughi in Italia durante la Grande Guerra (Rome: Laterza); E. Ellero (2001) Storia di un esodo: I friulani dopo la rotta di Caporetto 1917-1919 (Pasian di Prato: Ifsml).

62. See L. Cadeddu (2006) La leggenda del soldato sconosciuto all'altare della patria (Udine: Gaspari), pp. 64, 80, 109-13; A. Baù (2002) 'I figli miei che non son più miei: Note sulla condizione delle vedove di guerra in Padova nel primo dopoguerra (1923-1927)', Venetica, 5, pp. 79-104.

63. See M. Casalini (2001) 'I socialisti e le donne. Dalla mobilitazione pacifista alla smobilitazione postbellica', Italia contemporanea, 222, pp. 5-41.

64. A. Bravo and A. M. Bruzzone (1995) In guerra senza armi: Storie di donne 1940-1945 (Rome: Laterza), p. 10. For example, flight and occupation - mainly female experiences - were omitted because they were a symbol of national defeat. These dramatic events became 'local memories' and were removed from the national collective memory until almost the 1990s, when historians started to study war violence in the areas along the Italian border.

65. The decree was signed on 29 April 1997; see Associazione Amici delle Alpi Carniche (1997) Le portatrici carniche (Tolmezzo: Moro), p. 16.

66. See ACAU, Visite pastorali, Flaipano 1921, Lusevera 1922, S. Leonardo 1923.

67. In post-war parish reports, widows were often criticized for their 'illegitimate relationships' with men. See, for example, ACAU, Visite pastorali, Resia 1919. 